\title{
Titus Burckhardt ve Mimaride Dini Sembolizm
}

\section{İsmail TAȘPINAR}

\section{Titus Burckhardt and Religious Symbolism in Architecture}

Citation/@: Taşpınar, İsmail, (2017). Titus Burckhardt and Religious Symbolism in Architecture, Milel ve Nihal, 14 (2), 160-174.

Abstract: Titus Burckhardt, was one of the most famous Traditionalist philosopher in the last century. He devoted his life to the study and exposition of the different aspects of Wisdom and Tradition. Burckhardt was one of the most remarkable exponents of universal truth, in the realm of metaphysics as well as in the realm of cosmology and of traditional art. This article aims to explain some aspects of his approach to the architecture in general and the Islamic architecture especially. The 'unity' is the principal dimension of the Islamic architecture. According to Burckhardt, the Ka'ba is the very primordial architecture on the earth that has an cosmologic symbolism. It has literally central importance for its architecture. Every Muslim faces the Ka'ba to recite the canonical prayers, and every mosque is accordingly orientated in this direction. For Burckhardt, the non using of image or as he says the 'aniconism' is also one of the most exeptional part of Islamic art and architecture. According to him, the aniconism preserves the primordial dignity of man, whose form, 'made in the image of God'; on the other hand, nothing that could possibly be an idol, may interpose itself between man and the invisible presence of God.

Key Words: Titus Burckhardt, Traditionalist, Islamic architecture, symbolism, aniconism.

Prof. Dr., Marmara Üniversitesi, İlahiyat Fakültesi, Dinler Tarihi Anabilim Dalı [itaspinar@marmara.edu.tr] 
Atıf/C: Taşpınar, İsmail, (2017). Titus Burckhardt ve Mimaride Dini Sembolizm, Milel ve Nihal, 14 (2), 160-174.

Öz: Titus Burckhardt, Gelenekselci Ekole mensup en önemli filozoflardan biridir. Araştırmalarını Hikmet ve Geleneğin metafizik boyutları ve onların sanat ve mimarideki tezahürleri üzerinde yapan Burckhardt, düşüncelerini İslam sanatı ve mimarisindeki çalışmalarıyla ortaya koymuştur. Makalede Burckhardt'ın Gelenekselci sanat bakış açısına göre mimari yapılara dair görüşleri ele alınmaktadır. Burckhardt'a göre, İslam mimarisinin en önemli özelliği, 'birlik' yani 'tevhid' sembolizmi dayalı bir yapıya sahip olmasıdır. Kabe, İslam'ın ilk mimari yapısı olması hem de sembolizmi bakımından merkezi bir öneme sahiptir. Burckhardt, İslam dini mimarisinde özellikle ikonalara yer verilmemesini Tanrı ile insan arasında hiçbir varlığın yer alamayacağını ifade eden 'anikonizm' ya da 'ikonasızcılık' olarak tanımlamaktadır.

Anahtar Kelimeler: Titus Burckhardt, Gelenekselcilik, İslam mimarisi, sembolizm, anikonizm.

'Allah güzeldir, güzeli sever.' (Allahu Cemîlün, yühibbü'l-Cemâl)

Hadis-i Şerif ${ }^{1}$

\section{Giriş}

İslam'da insanlar kutsanmış din adamları ve halk olmak üzere ikiye ayrılmadıkları gibi, mekanlar da kutsal ve dünyevî şeklinde bir ayrıma tabi tutulmamıştır. Bu yüzden, Titus Burckhardt'ın (1908-1984) da mensup olduğu Gelenekselci Ekol'e göre, İslam mimarisi olarak inşa edilmiş olan yeryüzündeki dini ve sivil bütün yapılarda onun metafizik değerlerinin izi farklı üslup veya tarzlarda yansıtılmıştır. İslam tarihinin daha ilk yıllarından itibaren farklı ülkelerin kültürüyle karşılaşan Müslümanlar, gittikleri yerlerde karşılaştıkları yapıların sadece birer taklitçileri olmamışlardır. Onlar, İslam'ın temel esasları olan tevhid ve güzellik anlayışlarını, fethettikleri ülkelerin mimarisiyle yeniden yoğurmuşlar ve metafizik derinliği olan özgün yapılarda bunları ifade etmişlerdir.

Burckhardt, İslam'ın metafizik değerlerinin mimari yapılarda farklı coğrafyalarda ve farklı şekillerde olsa dahi bir şekilde varlığ1nın görülebileceğini ve hissedilebileceğini belirtmektedir. Ona göre bu durum, aynı metafizik değerlere sahip ortak bir geleneğe bağlı

1 Burckhardt'ın da mensup olduğu Gelenekselci Ekolün İslam mimari sanatına dair yazdıkları eserde sık sık zikrettikleri bir hadis-i şeriftir. 
olmaktan kaynaklanmaktadır. Araştırmada, Titus Burckhardt'ın genel olarak mimari sanata ve özel olarak İslam mimarisinin sembolizmine dair yazmış olduğu Mirror of the Intellect, Essays on Traditional Science \& Sacred Art ${ }^{2}$ ile Art of Islam, Language and Meaning ${ }^{3}$ adl 1 eserlerinden ve çeşitli makalelerinden hareketle, onun bu konudaki temel düşünceleri ele alınmaktadır.

Çalışma iki kısımdan oluşmaktadır. Birinci kısımda, Titus Burckhardt'ın geleneksel sanat ve onun mimari yapılardaki ifadesine dair temel fikirleri incelenmektedir. Dinî Mimaride Sembolizm başlı̆̆ını taşıyan İkinci Kısım'da ise, Burckhardt'ın İslam mimarisinin temel sembolizmlerine dair değerlendirmelerine değinilecektir. Araştırmanın sonuç kısmında genel bir değerlendirme yer almaktadir.

\section{Titus Burckhardt ve Geleneksel Sanat Açısından Mimarî Yapı- lar}

Burckhardt, bir sanat eseri olarak mimarî yapı ve onun ortaya çıkması konusunda özellikle bu eseri vücuda getirmek için çalışan sanatkar ile zanaatkarın eğitimi ile yakından ilgilenmektedir. Ona göre, bu konulardaki eğitim sözle aktarılmaz. Çırak ustasını çalışırken izler ve onu taklit eder. Burckhardt'a göre, bu taklide dayalı eğitim yalnızca bir yöntemin aktarılması şeklinde gerçekleşen bir eğitim değildir. İyi bir sanatkar ve zanaatkar; sabır, disiplin ve içtenlik gibi bir dizi insanî değerleriyle ayırt edilir. Bu yönüyle, geleneksel sanatın pedagojik niteliğini küçümsemek kolay değildir. ${ }^{4}$

Burckhardt, mimarinin de içinde yer aldığ 1 plastik sanatlarda özellikle yaratıcılık ile geleneksel bakışın nasıl uzlaşabileceği konusuna da açılık getirmektedir. Ona göre, bu konuda gelenek sanatçıya koşullara veya çalışmasının amacına göre kullanılıp uyarlayacağı bir dizi model ya da tipik biçimler vermesini sağlayacaktır. $\mathrm{O}$, sanatçı ile gelenek arasındaki bu ilişkiyi, kişinin dil ve

2 Bu eserin Türkçe tercümesi Aklın Aynası, Geleneksel Bilim ve Kutsal Üzerine Denemeler (çev.: Volkan Ersoy, İstanbul 1997) başlığ ile yayınlanmıştır.

3 Araştırmada, bu eserin İngilizce aslı ile birlikte Fransızca tercümesi olan ve L'Art de l'Islam, Langage et Signification (Paris, 1985) başlığını taşıyan baskısından da istifade edilmiştir.

4 Titus Burckhardt, Aklın Aynası, çev.: Volkan Ersoy, İstanbul 1997, s. 199. 
onun kuralları ile olan ilişkisine benzetir. Yani sanatçı, yapacağı sanatı geleneğin ona sunduğu kurallara adapte ederek ve belirli yasalara uyarak gerçekleştirir. Dilin sahip olduğu gramer ve sentaks gibi gelenek de modeller ve kendine özgü tipik biçimler sunar. Bir dilde ustalık elde eden kişi, dilin kurallarına uygun olarak şaheserler verebildiği gibi; sanatçı da geleneğin imkanlarını kullanarak mimaride şaheserler verebilir. Öyle ki, bir edebiyatçı dilin kaynaklarını kullanarak kendini özgürce ifade ederken, bir sanatçı olan mimar da geleneğin kaynaklarından beslenerek eserlerini özgürce gerçekleştirebilir. Bu nedenle Burckhardt'a göre, İslam mimarisinin ilk fetihlerde karşılaşılan Bizans kiliselerine bir tepki olarak geliştiğini söylemek, asırlar boyu sürecek iç dengeye sahip bir mimari anlayışı ve onun sunduğu imkanları sıradan bir duygusallıkla izah etmek basitliğine düşme anlamına gelmektedir. ${ }^{5}$

Geleneğe bağlı sanatçının, yapılış amacına uygun ve yeterli olan mimari eserini geleneğin kaynaklarından beslenerek vücuda getirmesi, o esere birey-ötesi bir derinlik de katacaktır. Burckhardt'a göre, bu durum gelenekten beslenen sanatın köklerinin Kur'an'a dayanmasındandır. İslam biliminin köklerinin Kur'an'a dayanması gibi, mimarinin de içinde bulunduğu sanatın tipik biçimlerinin kökleri İslam'ın ruhuna sahiptir ve onun izlerini taşır. ${ }^{6}$ Bu konuda Titus Burckhardt, modern bilim anlayışının bir uzantısı olan sanat tarihçilerinin geleneğe dayanan bu perspektife sahip olmadıkları için herhangi bir İslam mimarisini ele alırken onun kendisinden önce gelen Bizans, Sasani, Kıpti gibi bazı sanatlarla irtibatını kurarak açıklamaya çalışmalarını eleştirir. Onlar, analizlerini yaparken şeylerin nesnel bilgilerine dair bilgi verseler dahi, o şeylerin asıl bilgisini vermezler.7 Yani, bir yapıdaki duvara bakan kişiye o duvarın 'varlık nedeni' (raison d'être) hakkında bir şey söylemezler. Oysa onların kavrayamadığı İslam sanatının ve dolayısıyla mimarisinin öz

\footnotetext{
Titus Burckhardt, L'Art de l'Islam, Langage et Signification, Paris 1985, s. 27.

Titus Burckhardt, Aklın Aynasl, s. 200.

Gerçekten, Titus Burckhardt'ın da belirttiği gibi, İslam mimarını anlatan İslam sanatına dair eserlerde, mimari yapının sembolizmine dair çok az bilgi verilmektedir. Buna karşın; kullanılan malzemeler, yapılardaki kubbe-mekan ilişkisi, farklı İslam ülkelerindeki yapıların tarihi ve benzeri nesnel konulara dair geniş açıklamalar yer almaktadır. Bu konuda örnek olarak bkz.: Selçuk Mülayim, İslâm Sanatı, İstanbul 2013, s. 55-95.
} 
yapısından gelen orijinal bir 'birliğin' (tevhid) varlığı ve İslam'ın ödünç aldığı tüm sanat unsurlarına kendi damgasını vurmuş olduğu gerçeğidir. ${ }^{8}$

Sanat ve dolayısıyla mimari yapıların asıl niteliklerin onlardaki güzellik ve o güzelliği ortaya çıaran psikolojik atmosferle irtibatlıdır. İslam'ın temel kaynaklarında ifadesini bulan metafizik esaslara dayalı Geleneksel sanat eserini anlamak için onun ortaya serebileceği manevi gerçek ihmal edilmemelidir. İslam sanatını üreten Müslüman sanatçı, ilahî kanunlara boyun eğdiği için, ürettiği sanat eserindeki güzelliği üretenin ya da yaratanın kendisi olmadığını bilir. $\mathrm{O}$, sanat eserindeki güzelliğin ancak kâinatta var olan düzene itaat ettiği oranda güzel olduğu ve bu yüzden evrensel güzelliği yansıttığı gerçeğinin bilincindedir. Titus Burckhardt'a göre, İslam sanat ve mimarisine yücelik ve insanüstü bir nitelik kazandıran budur. Bu yüzden, geleneğe dayanan bu sanat eseri, 'elhamdülillâhi vahdeh $\hat{u}^{\prime}$ sözünde ifadesini bulan insana bir olan Allah'1 tanıtır. ${ }^{9}$

Avrupa'daki figüratif sanatın ön planda tutulmasını canlı imgeye önem verilmesiyle açıklayan Burckhardt, İslam sanatında bunun tam aksine insanın doğal olarak çevresini kuşatan nesnelere önem verildiğini belirtir. Bu yüzden, insan çevresini kuşatan ev, çeşme, su taşı gibi mimari nesnelerin kendi doğalarına uygun bir şekilde yapımı İslam mimari sanatının merkezinde yer alır. Meselâ, bir binanın kusursuz hale getirilmesi üç boyutlu geometriye dayanır. Üç boyutlu geometrik şekle sahip olması ise, billur durumundaki maddenin mükemmelliğini izlediği içindir. İslam sanatı öz olarak nesnel olduğu için, kubbenin en gerçek profilini aramaz. Bu yüzden, mimarî önemli bir sanattır. Burckhardt, mimarînin insanın çevresine şekil veren ve çevreyi İslamî ‘berekete' uygun kılan sanatlar içinde önemli bir yer işgal ettiğini belirtir. Burckhardt'a göre ağaç, işleme, mozaik, heykel gibi yardımcı el sanatlarının çoğu mimariye bağlıdır. Geleneksel terminolojiye göre bunlara 'yardımcı sanatlar' denir. Ancak, bunlar İslam dünyasında hiçbir zaman daha önemsiz bir yere sahip değildirler. Çünkü bunlar da 'Allah'ın yeryüzündeki temsilcisi' (halife) olarak insanın saygınlığını taşırlar. ${ }^{10}$

\footnotetext{
Titus Burckhardt, Aklın Aynası, s. 229-230.

Titus Burckhardt, Aklın Aynasl, s. 230.

10 Titus Burckhardt, Akln Aynası, s. 233.
} 
Burckhardt, İslam sanatıyla geometri arasında, ilahî sıfatların sanatsal ifadesinin bilimle olan ilişkisine dayandığını belirtmektedir. Geometri ilmi, sanatçının temel geometrik şekillerden ahenkli biçimler geliştirmesine izin veren bir ilim olduğu için; mimari yapılar, ilahi sıfatların ifadesi olan bu geometrik şekillerin ahengini yansitan en belirgin sanat eserleridir. Bu yüzden; Tunus, Kurtuba, Kahire, Isfahan, Herat ve diğer şehirlerdeki büyük camiler, onları yaratan mimarların düşünce yapısı kavranmadan anlaşılamazlar. ${ }^{11}$

Burckhardt, İslam mimari sanatının bir diğer önemli özelliği olarak tespit ettiği 'boşluk' kavramı üzerinde durur. Ona göre mimari yapılardaki bu 'boşluk', dünyanın kargaşa ve telaşından azade, denge, huzur ve barışın bir ifadesidir. Burckhardt'a göre bu, İslam mimarisinin sükunetin koşullarını sağlaması bakımından ne kadar merkezi bir önem taşıdığının en güzel göstergesidir. Nitekim Hz. Peygamber'in, Allah'ın kullarına 'yeryüzünü ibadet yeri olarak bahşettiğini' belirtirken, mimarlığın insanoğlunun yaşadığı her yerde saflık ve sükunetin koşullarını yeniden tesis etmesine dikkat çekmektedir. ${ }^{12}$ Yaratıcı'nın elindeki izlere benzeyen bakir doğanın söz konusu olduğu yerde, bu güzellik mimarlık tarafından farklı düzeylerde gerçekleştirilir. Burckhardt, böyle bir metafizik derinliğe sahip olan mimarlıkta, bakir doğanın sunduğu 'boş alan'ın işlenmesinde, hem insan aklının kavrayışına uygun olması nedeniyle belli bir sınırlama vardır hem de insanın her türlü kuraldan azade bireysel tutkularını keyfi olarak kullanımını engeller. ${ }^{13}$

'Boşluk' kuramını cami mimarisine uygulayan Burckhardt, camiye giren bir müminin sadece bir ziyaretçi olmadığını, gerçekte 'asıl evinde' olduğunu belirtir. Kendini her türlü tesadüfî değişikliklerden arındıran abdestini alıp camiye giren bir mümin, Kur'an

\footnotetext{
Titus Burckhardt, Aklın Aynasl, s. 237.

Müslümanların ibadet yerlerindeki huzurun gerçekleşmesinde mimari yapıların durumu ile ilgili kiliseden camiye çevrilen yapılarda da izlendiğini belirten Burckhardt, bu konuda katedrallerin ortasında uzanan kemerler ana mekanı kesmesine izin vermemesi için bazı tadilatların yapıldığını belirtir. Bkz.: Titus Burckhardt, Aklın Aynası, s. 244-245.

13 Titus Burckhardt, Aklın Aynası, s. 243.
} 
ayetlerinin okunmasıyla birlikte, sembolik olarak dünyanın merkezine ve Hz. Adem'in makamına varır. İşte, Müslüman mimarların tamamı camilerde rahat ve her yeri gösteren bir alan yaratmaya gayret ederler. Bu yapılardaki 'makamlar'ın tamamında bu düzlem zenginliğine rastlanır. Burckhardt, bu konuda Türkiye' deki camileri örnek verir ve o yapıların merkezi kubbeleri ile onu çevreleyen sütunların ortaya çıkardığı alanın yer ile gök arasındaki bütün gerilimi ortadan kaldırdığını belirtir. ${ }^{14}$ Hatta, İslam mimarisindeki süslemenin de duvarların ve sütunların çıplak bedenlerini kaybederek boş bir alanın yaratılmasına neden olduğu için, İslam mimarisindeki iç mekanda geniş beyaz yüzeylerin etkisi daha da artar. ${ }^{15}$

\section{Dini Mimaride Sembolizm}

Burckhard, dini mimarideki sembolizmi incelerken özellikle İslam'ın temel inancı olan 'tevhid' ya da 'birlik' sembolizmi üzerinde durmaktadır. Tevhid sembolizminin mücessem temsili olan Kabe ise, kozmolojik derinliği olan bir sembolizmi yansıtmaktadır. Bütün bu yapılarda dikkat çeken en önemli hususlardan biri ise, süslemelerde ikonaların kullanılmamış olmasıdır. Burckhard'a göre, İslam mimarisinde canlı varlıkların temsili olan 'ikonacılık' değil, 'ikonasızcılık' olarak da tanımlanabilecek olan 'anikonizm' anlayışı geçerlidir.

\section{a. Burckhardt'a Göre Mimaride Birlik (Tevhid) Sembolizmi}

Burckhardt, İslami yapıları işleyen zanaatkarların kullandıkları maddeler her ne kadar mutevazi ve araçları çok basit olsa da, eserleri her zaman soylu olmaktadır. Bunun nedeni, güzelliğin İslam'ın bizzat yapısında olmasındandır. Bu, onun kendisini adalet ve cömertlik (kerem) olarak açığa vuran 'Birlik' (tevhid) olmasının en temel gerçekliğinden kaynaklanır. Bu üç nitelik; birlik, adalet ve cömertlik, onlara birlik, denge ve bolluk dediğimizde daha açıkça görüleceği gibi, güzelliğin de temel özellikleridir. Güzellik tanımı bunlara dayanır. Çünkü; sanatsal düzlemde 'adalet' dengeyi oluşturur, 'cömertlik' bolluğu oluşturur, 'birlik' ise tüm mükemmel şeylerin ortak kaynağıdır. İslam mimarisinde güzele ne kadar önem verildiğini göstermek için Burckhardt, Arap mimarların kemer için

14 Titus Burckhardt, Aklin Aynasl, s. 244.

15 Titus Burckhardt'ın Türk Osmanlı mimarisine dair geniş açıklamaları için bkz.: Titus Burckhardt, L'Art de l'Islam, Langage et Signification, Paris 1985, s. 238-247. 
kullandıkları 'revak' kelimesini örnek verir. Arapça'da revak kelimesi, 'güzel, zarif ve saf' anlamlarına gelmektedir. İslam mimarisinde tipik iki tür kemeri vardır, bunlardan biri gemi omurgası biçimindeki İran kemeri, diğeri ise nal biçimindeki Mağrib kemeridir. Burckhardt, her ikisinin de İslam mimarisinin temel özellikleri olan durağan dinginliği ve ışığı bünyesinde barındırdığını belirtir. ${ }^{16}$

İslam tasavvuf metafiziğini incelerken aktarılması gereken temel kavramlardan (doctrines ésotériques) biri olarak kabul ettiği ‘tevhid' kavramından hareket eden Burckhardt, ${ }^{17}$ mimarlık eğitiminde mimarideki 'tevhid' gerçeğinin bilgisinin aktarılmasının geleneksel mimari mirasın anlaşılmasında en önemli bilgilendirme olacağını belirtir. Öğrenciler, çömlekçilikten kubbe örmeye kadar çeşitli sanatların teknik işlerini veya belli bir binanın oranlamasını bize verecek geometrik şekilleri öğrenmelidirler. Ancak, büyük sanat mirası sadece bir nesneden ibaret değildir. Burckhardt'a göre o miras, kaynağını 'tevhid'den alan manevi bir bakışla birlikte teknik beceriyi birleştiren bir yöntem olarak geleneksel sanatın kendisidir. ${ }^{18}$

Burckhardt, bu yüzden cami mimarisindeki merkezi kubbe ile sütunların oluşturduğu birlik ve caminin her yerindeki müminleri kucaklayan bütünlüğe dikkat çeker. Camilerdeki çokgen tabanlı kubbeler ve taşları tam yuvalarına oturmuş kemerler hep bu simgeselliğin bir yansımasıdır. ${ }^{19}$ Kiliselerin aksine, bir camide belli bir yerde dua merkezi yoktur. Camilerde, bütün iç mekan her yandaki müminleri kucaklayan 'bir olan Varlık'ı ima edecek tarzda düzenlenmiştir. İsrailoğulları, Süleyman Mabedi'nde ibadet ederken Doğu'dan Batı'ya doğru yöneliyorlardı. Mabed'in yıkılması ve Ya-

16 Titus Burckhardt, Aklın Aynasl, s. 233, 245.

17 Titus Burckhardt, Introduction Aux Doctrines Ésotériques de l'Islam, 'Fondements Doctrinaux: Des Aspects de l'Unité', Paris 1985, s. 73-81.

18 Titus Burckhardt, Akln Aynası, s. 238.

19 İslam mimarisinde cami, genellikle ortasında çeşmenin yer aldığı geniş bir bahçeye sahiptir. Çeşmenin üstünde çoğu zaman küçük bir kubbe yer alır. Geniş bir bahçesi, ortasında yer alan bir çeşmesi ve oradan dört bir yana doğru suların aktığı bir yer olarak tanzim edilen bu mekan, adeta Cennet'in bir kopyası niteliğindedir. Zira Kur'an'da da Cennet, insanların içinde mutlu olacakları ve altlarından irmakların aktığı bir yer olarak tasvir edilmektedir. Bkz.: Titus Burckhardt, The Essential Titus Burckhardt, Reflections on Sacred Art, Faiths and Civilisations, edit.: William Stoddart, Indiana 2005, s. 151. 
hudiler'in Babil Sürgünü'ne gitmesi ile birlikte, ibadetlerini Mabed'in bulunduğu şehir olan Kudüs'e doğru dönerek icra etmeye başladılar. ${ }^{20}$ Hıristiyanlar ise; başlangıçta Yahudiler gibi Kudüs'e doğru ibadet etmekte idiler. Ancak, Yahudiler'le bağlarını kopardıktan sonra Hıristiyanlar, ibadet ederken yönlerini Batı'ya doğru, bazen de Doğu'ya doğru çeviriyorlardı. Hıristiyanlık'ta, ibadet ederken Doğu'ya dönmenin bir ilke olarak uygulanmaya başlaması 12. Yüzyıldan sonra olacaktır. ${ }^{21}$ Mihrap ise, ibadetin yapılacağ 1 yön olan sadece Mekke istikametini gösterir. ${ }^{22}$

\section{b. Kabe Mimarisinde Kozmolojik Sembolizm}

Kabe, İslam dininin yeryüzündeki en mukaddes mimari yapısı olması nedeniyle onun hem şekli hem de sembolizmi birçok araştırmacının dikkatini çekmiştir. Burckhardt'a göre, İslam mimarisine dair açıklama yapmak için öncelikle Kabe'nin tasviri, litürjideki yeri ve sembolizmine dair bilgi sahibi olmak gerekmektedir. Namaz için bütün Müslümanların kendisine yöneldiği, dünyadaki bütün camilerin kendisine doğru inşa edildiği Kabe, İslam tarihinde dinî mimariye ait ilk yapı olması bakımından da özel bir yere sahiptir. Burckhardt'a göre, Kabe her ne kadar kelimenin tam anlamiyla bir 'sanat' eseri olmasa da, basit bir kübik yapı olması hasebiyle onun bir 'proto-sanat' yapısı olduğunu söylemek doğru olacaktır. Bununla beraber, sahip olduğu manevi boyut ve hem şekli hem de etrafında gerçekleştirilen ritüeller bakımından kendisinden sonra

$20 \quad$ Bkz.: I. Krallar, 8/48: 'tutsak oldukları ülkede candan ve yürekten sana dönerlerse, atalarına verdiğin ülkelerine, seçtiğin kente ve adına yaptırdığım tapınă̆ına yönelip dua ederlerse'; Daniel, 6/10: 'Daniel yasanın imzalandığını öğrenince evine gitti. Yukarı odasının Yeruşalim yönüne bakan pencereleri açıktı. Daha önce yaptığı gibi her gün üç kez diz çöküp dua etti, Tanrısı'na övgüler sundu.'

21 Kiliseler'in mihraplarının Doğu'ya doğru bakması, ahir zamanda Mesih'in ikinci gelişinin Doğu'dan olacağına dair Matta İncili'ndeki (24/27) 'Çünkü İnsanoğlu'nun gelişi, doğuda çakıp batıya kadar her taraftan görülen şimşek gibi olacaktır.' İle Luka İncili'ndeki (1/78-79) 'Çünkü Tanrımız'ın yüreği merhamet doludur. O'nun merhameti sayesinde, Yücelerden doğan Güneş, Karanlıkta ve ölümün gölgesinde yaşayanlara ışı saçmak Ve ayaklarımızı esenlik yoluna yöneltmek üzere Yardımımıza gelecektir.' ifadelerine dayanmaktadır.

22 Türk cami mimarisine bu yönüyle özel bir önem veren Titus Burckhardt, Mimar Sinan'ın bu 'birlik' (vahdet) sembolizmini mimari yapılarında nasıl gerçekleştirdiğini özel olarak açıklar. Bkz.: Titus Burckhardt, Aklın Aynası, s. 244. 
inşa edilecek olan mimari yapıların bütün özelliklerini kendi özünde taşıdığını söylemek mümkündür. ${ }^{23}$

İbrahimî gelenek ile olan bağa işaret eden Kabe, aynı zamanda monoteist dinlerle ayn kökene sahip olduğunun da bir işaretidir. Nitekim, Kur'an' da Hz. İbrahim 'Arapların atası' olarak değil, 'tevhid inancının atası' olarak takdim edilmektedir. ${ }^{24}$ Mekke'deki Kabe'nin yapısının ne kadar 'arkaik' bir yapı olduğunun en belirgin özelliği, onun aynı zamanda Hz. İbrahim dönemine ait olduğunun da bir göstergesidir. Burckhardt'a göre, bunun en açık delili, her ne kadar birçok defa yıkılıp yeniden yapılmış olsa da, isminin de çağrıştırdığı 'küb' şekli onun ilk yapısıyla aynı olduğunun da bir kanıtıdır. Kabe'nin bir örtü ile 'örtünmesi', antik greko-romen kültüründe olduğu gibi, söz konusu mabedin 'canlı' olduğu ve etrafını manevi olarak etkilediğinin bir işaretidir. Gökten düşen her taşın kutsal kabul edildiği antik dönemde olduğu gibi, 'gökten düştüğüne' inanılan Hacerü'l-Esved de Kabe'nin güney köşesine yerleştirilmiştir. ${ }^{25}$

Yahudilerin kutsal mabedi olan Süleyman Mabedi'nin en kutsal yeri ve 'İlahî huzûr'un (şekîna) mevcut olduğu kabul edilen Kutsallar Kutsalı'nın (Kodeş ha-Kodeşîm) şekli de Kabe gibi 'küb' şeklinde idi. Bu durum, bazı Hindu mabetlerinde de mevcuttur. Hindu mabedlerinin merkezinde yer alan, 'ana rahmi' (gharbagrha) olarak isimlendirilen ve en kutsal mekan olarak kabul edilen yer de ' küb' şeklindedir. ${ }^{26}$ Kabe' de yer alan perdenin adı da 'Rahmân perdesi'dir. Süleyman Mabedi'nde küb şeklindeki Kutsallar Kutsalı'nın içinde Ahid Sandığı (Aron ha-Brit) yer almakta idi. Oysa, ‘Beytullah' yani Allah'ın Evi' olan Kabe'nin içi boştur. Hıristiyan kutsal kitabı Yeni Ahid'in son kitabı olan Yuhanna'nın Vahyi adlı

23 Titus Burckhardt, L'Art de l'Islam, Langage et Signification, Paris 1985, s. 15-16.

24 Âl-i İmrân, 67: 'İbrahim ne Yahudi ne de Hıristiyandı. Fakat hakka ve tevhide yönelen bir Müslümandı.'

25 Titus Burckhardt, L'Art de l'Islam, Langage et Signification, Paris 1985, s. 18.

26 Heather Elgood, Hinduism and the Religious Arts, New York 2000, s. 99. 
metinde Semâvî Kudüs, bütün dünyanın bir sentezi olarak takdim edilmektedir ve o da küb şeklinde tasvir edilmektedir. ${ }^{27}$

Burckhardt, küb şeklinin 'merkez fikri' ile bağlantılı olduğunu belirtmektedir. Küb şekli, mekanın tamamının sentezini içermektedir ve her bir yüzü ana yönlerden birine tekabül etmektedir: Tepe, aşağ1 ve dört ana yön. Kabe'nin dört ana yönünü temsil eden köşeleri de, geleneğe göre 'âlemin sütunları'dır (erkânü'l-âlem). Yeryüzünün merkezi ise, gökteki 'mihver'in tam da ortasından geçtiği Kabe'nin merkezinde yer alan noktadır. Kabe'nin etrafında gerçekleşen tavafın merkezinde de bu mihver vardır. ${ }^{28}$ İslam kaynakları, Kabe'nin mihver konumuna dair çeşitli rivayetler nakletmektedir. Buna göre, ilk defa Hz. Adem tarafından inşa edilen, daha sonra Tufan ile birlikte yıkılan ve tekrar Hz. İbrahim tarafından inşa edilen Kabe, Arş-1 Âlâ'dan semavi katların tamamından geçerek yeryüzüne kadar inen bir mihverin en ucunda yer almaktadır. Arş-1 Âlâ'nın etrafında melekler tavaf ettiği gibi, bu mihverin etrafı da her semavi katta yer alan melekler tarafından tavaf edilmektedir. ${ }^{29}$

Cami ve mescitlerin 'yönlerinin' Kabe'ye doğru olarak inşa edilmesinin sembolizmine de değinen Burckhardt, bunu Hiristiyan mabedlerinin yönelişleri ile mukayese ederek izah etmekte. Kiliselerin yönleri, hz. İsa'nın öldükten sonra dirilişini temsil eden Güneş'in doğuşundan hareketle, Doğu'ya doğru bakmaktadır. Bu yüzden kiliselerin tamamının yönü birbirine paralel mihvere sahip olarak hizalanmaktadır. Oysa, Müslümanların cami ve mescitlerinin tamamının yönü, yeryüzünün merkezi olan Kabe'ye bakmaktadır ve hepsi de aynı noktada ve aynı mihverde buluşmaktadır. ${ }^{30}$ Burckhardt'a göre bu, Müslümanların toplu olarak iradelerini tek

27 Yuhanna'nın Vahyi, 21/16: 'Ve şehir (Semâvî Kudüs) dört köşeli olup, onun uzunluğu genişliği kadardır. Ve şehri kamışla ölçtü, on iki bin ok atımı idi; onun uzunluğu ve genişliği ve yüksekliği müsavidir.'

28 Mabedlerin veya kutsal kabul edilen mekanların etrafında tavaf yapılması, Hinduizm ve Budizm'de olduğu gibi Ortaçağ Hıristiyanlığı'nda rastlanmaktadır. Dinlerde kutsal mekanların etrafında tavaf ve sembolizmine dair bkz.: İsmail Taşpınar, Doğu Dinlerinde Hac İbadeti, Hinduizm ve Budizm, İstanbul 2016.

29 İslam kaynaklarında tavafın sembolizmine dair geniş açıklama için bkz.: Malek Chebel, Dictionnaire des Symboles Musulmans, Rites, Mystique et Civilisation, Paris 1995, s. 101-102.

30 Titus Burckhardt, bu yorumuna mesned olarak Kur'an-1 Kerim'de yer alan şu ayete işaret etmektedir: 'Dönüş yalnız Allah'adır', (Âl-i İmrân, 3/28). 
bir İrade'ye boyun eğdiklerini ve ona teslim olduklarını sembolize etmektedir. Nitekim, bu nedenle Kabe'nin içinde yön diye bir şey yoktur ve her türlü yöneliş bu mihverde nihayet bulur. ${ }^{31}$

Burckhardt'a göre, Müslüman ruhunda olduğu gibi İslam mimarisi ve sanatı, greko-romen sanata ve onun dünyasina nispetle Yahudi kutsal kitabı olan Eski Ahid'de hayatları anlatılan büyük peygamberlerin dünyasına ve dolayısıyla onların mimari sanatına daha yakındır. İslam, dönemin iki güçlü ülkesi olan Persler ve Bizanslılar'ın arasından siyrılıp kendi hayatiyetini devam ettirmeyi başarmıştır. ${ }^{32}$ İşte, natüralist ve rasyonalist bir sanat anlayışına sahip olan bu her iki medeniyetin aksine Kabe, zamansızlığın dibine doğru atılmış bir çapa misalidir. ${ }^{33}$

\section{c. İslamî Mimarîde İkonasızcılık ya da Anikonizm}

Burckhardt, İslam sanatının Avrupa sanatında olduğu gibi insan temsiline dair hiçbir şey sunmadığından modern 'psikolojiciler' tarafından 'kapalı kitap' olarak tanımlanmasını bir cehalet olarak nitelemektedir. Gerçekten, Avrupa sanatı ve mimari tezyinatın merkezini, hem Yunan hem de Hiristiyan ikonografisinden etkilendiği için, insan imgesi teşkil etmektedir. Oysa, İslam sanatında insan imgesi, daha çok minyatür sanatıyla ilişkisi düşünüldüğünde, ikincil bir öneme sahiptir ve ibadet alanlarının tamamen dışındadır. ${ }^{34}$

Burckhardt, konuyu insan-merkezli sanatın İslam sanatındaki ‘mutlak' ve 'şartlı' imkanı üzerinde durarak açıklamaktadır. İbadet nesnesi olması bakımından tüm imgeler mutlak olarak yasaktır. Oysa, canlı bedenlere öykünen sanatsal biçimler açısından ise, şarta bağlıdır. Avrupalı bakış açısı, figüratif sanatlar üzerindeki İslami kısıtlamayı aşırı bir tavır olarak görür. Hatta, daha da ileri gidilerek, insan

31 Titus Burckhardt, L'Art de l'Islam, Langage et Signification, Paris 1985, s. 20.

32 Hatta Burckhardt'a göre, nasıl ki Hıristiyan medeniyeti Sezar'ın inşa ettiği topraklar üzerinde bir medeniyet inşa ettiyse; İslam coğrafyası da Büyük İskender'in inşa ettiği dünyayı miras almıştır. Konuyla ilgili açıklamalar için bkz.: Titus Burckhardt, The Essential Titus Burckhardt, Reflections on Sacred Art, Faiths and Civilisations, edit.: William Stoddart, Indiana 2005, s. 150.

33 Titus Burckhardt, L'Art de l'Islam, Langage et Signification, Paris 1985, s. 22.

34 Anikonizmin şeklindeki mimari tezyinat sanatına aynı şekilde Hindu mabedlerinde de rastlanılmaktadır. Konuyla ilgili detaylı bilgi için bkz.: kullanılan Heather Elgood, Hinduism and the Religious Arts, New York 2000, s.70-71. 
figürüne yer verilmemesi İslam sanatlarındaki kültürel yoksulluğun sebebi olarak görülür. Burckhardt'a göre, İslamî sanatın 'anikonizm'i yani 'temsilsizlik' özelliği, asıl itibariyle imge ile imgeyi yaratan arasındaki diyalojik ilişkiye dayalı psikolojik aynalar oyununu reddetmesine dayanmaktadır. ${ }^{35}$ Sanatta; imgeyi yapanın, yaptığ1 imgenin büyüsünden kendini kurtaramaması, insanın her şeyden önce gelen değerini düşürmektedir. ${ }^{36}$ Burckhardt'a göre, İslam tezyinatı ve mimarisindeki insan imgesinin temsil edilmemesi olan 'anikonizm'in arkasındaki düşünce budur. ${ }^{37}$ Burckhardt, Mekke'nin fethi esnasında Hz. Peygamber'in Kabe'nin içine girdiğinde, kucağında çoçuk olan Hz. Meryem'in tasvirinin üzerini bir örtüyle örttükten sonra, onun dışındaki resimlerin tamamının silinmesi ve o kutsal yerin her türlü puttan arındırılmasını emretmesini aynı şekilde izah etmektedir. Bu davranışıyla Hz. Peygamber, insanların nezdinde her an putlaşabilme potansiyeli olan her şeyin kaldırılmasını göstermiştir. Süsleme sanatı olarak İslam mimarisinde bunun yerini hat sanatı alacaktır. ${ }^{38}$ Burckhardt'a göre, Arap harflerinden oluşan hat sanatının sahip olduğu kutsal ve 'arkaik' tabiatı, üzerine işlendiği yerlere zamanüstü veya ezelîliği (perennial) andıran bir boyut katmaktadır. ${ }^{39}$

35 Burckhardt'in insanların put edinmelerine yol açacak belli bir canlı form veya ikonanın dışında olanlar için kullandığı 'anikonik' kavramı, bazı araştırmacıların ise 'soyut form' ve sanat tarihçisi Selçuk Mülayim' in 'tanımsız form' dediği kavramı akla getirmektedir. İkonalar ve onların anlamı, yapıları, çeşitleri ve değişimlerine dair çalışmaları bulunan Selçuk Mülayim, ikonalardaki motiflerin, söz konusu ikonalara 'kimlik' kazandırdığını belirtir. Buna mukabil Selçuk Mülayim, genellikle geometrik şekillerde rastlandığını belirttiği ve nereden geldiği, neyin sonucu ortaya çıtığı bilinmeyen figürlere 'tanımsız figür' olarak isimlendirmektedir. Ona göre, sanat tarihi açısından deşifre edilememiş ve tanımlanamayan bu formlar ve motiflerin 'kimliği' belirsizdir. Konu ile ilgili detaylı açıklama için bkz.: Selçuk Mülayim, Türk Sanatında İkonografik Dönüşümler, Değişimin Tanıkları, İstanbul 2015, s. 269-276. Burckhardt bu yüzden 'put kırıcılığı anlamına gelen 'ikonoklazm' kavramı yerine 'temsilsizcilik' anlamına gelen 'anikonizm' kavramının daha doğru olacağını belirtir. Anikonizm'e dair geniş açılama için bkz.: Titus Burckhardt, L'Art de l'Islam, Langage et Signification, Paris 1985, s. 65-70. Titus Burckhardt, Aklın Aynası, s. 230-231. Titus Burckhardt, L'Art de l'Islam, Langage et Signification, Paris 1985, s. 22-23. vilisations, edit.: William Stoddart, Indiana 2005, s. 153-155. 
İslam sanatında canlı imge yasağının varlığı, mimari süslemede geometrik süslemenin olağanüstü gelişmesine neden olmuştur. Burckhardt'a göre, bu gelişmeyi imge yasağı ile oluşan boşluğun başka bir sanat türüyle kapatma gayreti olarak okumak doğru olmayacaktır. Yani, biri diğerinin karş1lı̆̆ değildir. Aksine, geometrik süsleme, imgenin zıddıdır ve tasvirin reddedilmesidir. Burckhardt'a göre, İslam sanatında imge ve tasvire karşı bu tavrın kökeni On Emir perspektifinde de görülebileceği üzere İbrahimî monoteist geleneğe dayanmaktadır. ${ }^{40}$ Arabesk süslemede, merkez hem her yerde hem hiçbir yerdedir; her olumlamanın arkasından bir 'inkar' gelir. Veya bunun tam tersi gerçekleşir. Burckhardt'a göre, bu sanatı icra eden sanatçı, yaratma coşkusundan hiçbir şey kaybetmeksizin zorunlu olarak yok olur. Geometrik sanat, az ihtiraslı ve daha çok tefekkür gerektiren bir sanattır. ${ }^{41}$

Bu çerçevede Burckhardt, 'canlı varlık resmi yapanlardan öteki dünyada onlara can vermelerinin isteneceği' şeklindeki hadisi ise; ${ }^{42}$ canlı varlık yanılsaması yaratmamaları koşuluyla insan-merkezli sanat biçimlerine hoşgörüyle bakılacağı şeklinde yorumlar. Burckhardt buna örnek olarak, minyatür resimde üç boyutlu uzayı gösteren merkezî perspektiften kaçınılmasını zikretmektedir. ${ }^{43}$

\section{Sonuç}

Titus Burchardt'a göre, geleneksel mimarinin temel karakteri, onun ilahi bir niteliği yansıtmasıdır. İlahi bir niteliği yansıttığı oranda bir mimari yapı güzel ya da mükemmeldir. Bu yüzden, İslam sanatındaki ve mimarideki metafizik boyutu anlamak ve mükemmelliği

40 Konuyla ilgili geniş açılamalar için bkz.: Titus Burckhardt, The Essential Titus Burckhardt, Reflections on Sacred Art, Faiths and Civilisations, edit.: William Stoddart, Indiana 2005, s. 151-153.

41 Titus Burckhardt, Aklın Aynası, s. 247-248.

42 Hz. Ayşe'den nakledilen hadis-i şerife göre, üzerinde suret bulunan yastığı görünce $\mathrm{Hz}$. Peygamber şöyle demektedir: ‘Bu suretleri yapanlar kiyamet günü azaba uğrar ve kendilerine: 'Yaptı̆̆ınız suretlere can verin bakalım' denir' buyurdu ve devamla: 'Içerisinde suretler bulunan eve melekler girmez' buyurdu. Hadis-i şerifin farklı rivayetleri için bkz.: Müttefekun Aleyh Hadisler, Buharî ve Müslim'in İttifak Ettikleri Hadisler, Haz.: Abdullah Feyzi Kocaer, İstanbul 2005, s. 564 .

43 Mimari tezyinatta mimarinin kullanımı ve sembolizmine dair geniş açıklama için bkz.: Titus Burckhardt, L'Art de l'Islam, Langage et Signification, Paris 1985, s. 7077. 
fark etmek için, o şeyin Allah'ın aynası olduğunu bilmek gerekmektedir. Mesela, geleneksel mimaride geometri bir yönüyle nicel boyutuyla sınırlı değildir. Aynı zamanda özellikle oran yasalarında açığa çıkan nitel bir boyut da vardır. Bu oran, ondaki eşsizlik özelliğini de kazandıran birliğindedir. Bu durum, temelde geleneksel olarak çizilen düzenli şekillerle dairenin bölünmesine dayanır. Böylece, bir mimari yapının bütün oranları sonuçta içinde varoluşun bütün imkanlarını taşıyan Varlığın Birliği'nin yani Vahdet-i vücûdun eksiksiz bir simgesi olan daireden kaynaklanır.

Geleneksel mimarinin varlığını devam ettiren en önemli temsilcilerinden biri olarak kabul edilen İslam mimarisi, Titus Burchardt'a göre hala keşfedilmeyi bekleyen birçok derin metafizik değerleri içinde barındıran simgelerden örülü bir yapıdır. İslam sanat tarihi eserlerinin sadece nesnel bilgiler vererek ele aldıkları mimari yapıların metafizik simgesellikleri ile incelenmesi gerektiğini vurgulayan Titus Burckhardt, bu araştırmayla da ortaya çıktığı üzere, ortaya çıkardığı simgeler ve geliştirdiği yeni perspektiflerle bu konuda yapılacak olan çalışmaların aynı zamanda en önemli temsilcilerinden ve öncülerinden biri olduğunu söylemek mümkündür.

\section{Kaynakça}

Heather Elgood, Hinduism and the Religious Arts, New York 2000.

İsmail Taşpınar, Doğu Dinlerinde Hac İbadeti, Hinduizm ve Budizm, İstanbul 2016.

Kitabı Mukaddes Eski ve Yeni Ahit, İstanbul 1996.

Malek Chebel, Dictionnaire des Symboles Musulmans, Rites, Mystique et Civilisation, Paris 1995.

Müttefekun Aleyh Hadisler, Buharî ve Müslim'in İtifak Ettikleri Hadisler, Haz.: Abdullah Feyzi Kocaer, İstanbul 2005.

Selçuk Mülayim, Türk Sanatında İkonografik Dönüşümler, Değişimin Tanıkları, İstanbul 2015.

Selçuk Mülayim, İslâm Sanatı, Ankara 2013.

Titus Burckhardt, L'Art de l'Islam, Langage et Signification, Paris 1985. 1985. -, Introduction Aux Doctrines Ésotériques de l'Islam, Paris , Aklın Aynası, çev.: Volkan Ersoy, İstanbul 1997. , The Essential Titus Burckhardt, Reflections on Sacred Art, Faiths and Civilisations, edit.: William Stoddart, Indiana 2005. 